\title{
Edukasi Usaha Budidaya Cacing Tubifex sebagai Salah Satu Peluang Ekonomi bagi Masyarakat Desa Lubuk Saban Kecamatan Pantai Cermin Kabupaten Serdang Bedagai
}

\author{
Emmy Syafitri ${ }^{1}$, Dwi Tika Afriani², Mekar Meilisa Amalia ${ }^{2}$ \\ 1,2 Universitas Dharmawangsa, Indonesia
}

\begin{abstract}
A B S T R A C T
THE EDUCATION OF TUBIFEX WORM CULTIVATION BUSINESS AS ONE OF THE ECONOMIC OPPORTUNITIES FOR PEOPLE OF LUBUK SABAN VILLAGE, PANTAI CEMIN DITRICT, SERDANG BEDAGAI REGENCY. Lubuk Saban is one of the areas whose population is engaged in aquaculture businesses where a large supply of freshwater fish is needed. Most farmers use artificial pellets which are relatively expensive, while the production cost can be reduced using natural food. Besides being cheaper, natural feed such as Tubifex are environmentally friendly. The purpose of this community service activity is to enable freshwater fish farmers in Lubuk Saban Village gain knowledge of Tubifex worm cultivation as one of the natural feed substitutes. In addition, this activity is expected to help the community in opening new business opportunities, provide natural food, reduce production costs, and improve the community's economy. The implementation of service activities is carried out using counseling methods with material exposure activities and direct practice regarding the stages of this Tubifex cultivation, with questionnaires and interactive discussions between devotees and students. From the results of community service activities conducted, it is concluded that participants of the service received new knowledge on the cultivation of Tubifex worms as one of the very promising economic opportunities. Furthermore, the servants gained field knowledge and new experiences on how to approach the general public, especially freshwater fish farmers.
\end{abstract}

Keywords: Cultivation, Education, Lubuk Saban Village, Tubifex Worm.

\begin{tabular}{llll}
\hline Received: & Revised: & Accepted: & Available online: \\
18.09 .2019 & 11.01 .2020 & 03.02 .2020 & 14.02 .2020 \\
\hline
\end{tabular}

\section{Suggested citation:}

Syafitri, E., Afriani, D., \& Amalia, M. (2020). Edukasi usaha budidaya cacing tubifex sebagai salah satu peluang ekonomi bagi masyarakat Desa Lubuk Saban Kecamatan Pantai Cermin Kabupaten Serdang Bedagai. Jurnal Pengabdian Pada Masyarakat, 5(1), 109-116. https://doi.org/10.30653/002.202051.265

Open Access I URL: http://ppm.ejournal.id/index.php/pengabdian/article/view/265

${ }^{1}$ Corresponding Author: Universitas Dharmawangsa. Jl. KL Yos Sudarso No.224, Glugur Kota, Kec. Medan Bar., Kota Medan, Sumatera Utara 20115, Indonesia; Email: esyafitri@dharmawangsa.ac.id 


\section{PENDAHULUAN}

Pengembangan perikanan budi daya air tawar selain meningkatkan nilai produksi juga untuk memenuhi kebutuhan protein ikan, memenuhi kebutuhan bahan baku pabrik, meningkatkan pendapatan dan juga membuka lapangan kerja. Lubuk Saban merupakan salah satu desa yang terdapat di Kecamatan Pantai Cermin kabupaten Serdang Bedagai yang penduduknya menekuni usaha perikanan budidaya. Spesies ikan yang dibudidayakan terdiri dari ikan mas, nila, lele dan bawal tawar dan juga ikan patin yang merupakan ikan introduksi baru. Kabupaten Serdang Bedagai juga terdapat perusahan asing PT. Aquafarm Nusantara yang memproduksi ikan nila merah dan nila gift untuk dieksport ke Eropa dan USA. Untuk budidaya perikanan air tawar, potensi tersebar di seluruh Kecamatan dengan luas lahan budidaya mencapai $2.008 \mathrm{Ha}$, kolam $463 \mathrm{Ha}$ dan kerambah 210 unit. Terdapat juga potensi perairan umum seluas 635 Ha dan waduk seluas $10 \mathrm{Ha}$.

Melihat dari tingginya potensi perikanan dan kelautan Serdang Bedagai, industri di sektor ini seharusnya berperan lebih nyata. Industri perikanan ini termasuk di dalamnya penyediaan fasilitas perikanan, pengembangan pengolahan dan pasca panen. Salah satu peluang usaha yang menjanjikan adalah penyedia pakan alami. Salah satu pakan alami yang mudah dibudidayakan adalah jenis Tubifex. Cacing sutra (Tubifex sp) mengandung kandungan yang sangat dibutuhkan sebagai pakan alami dalam kegiatan unit perbenihan, terutama pada fase awal (larva) karena memiliki kandungan nutrisi antara lain protein (57\%), lemak (13,3\%), serat kasar (2,04\%), kadar abu (3,6 \%) dan air $(87,7 \%)$ yang baik untuk pertumbuhan ikan (Bintaryanto \& Taufikurohmah, 2013) dan ukurannya sesuai dengan bukaan mulut larva dan mudah dicerna (Suharyadi, 2012). Pakan alami tidak banyak menurunkan kualitas air, terutama jenis pakan alami hidup karena pakan alami hidup yang tidak dimakan ikan tidak akan meninggalkan tumpukan bahan organik di dasar perairan. Pakan alami tetap hidup sampai ikan memangsanya kembali.

Kebutuhan cacing Tubifex dilapangan sangat tinggi, sementara pasokan yang berasal dari penjual tradisional belum mampu memenuhi kebutuhan dilapangan dan hasil tangkapan di alam pun masih berfluktuasi dan tidak kontiniu terutama pada saat musim penghujan, karena cacing sutera di alam terbawa oleh arus deras akibat curah hujan yang cukup tinggi (Setyaningrum, Sugiharto, \& Sukmaningrum, 2016). Oleh karena itu, dibutuhkan upaya untuk memenuhi kebutuhan cacing Tubifex dengan cara budidaya.

Tingginya kandungan gizi cacing Tubifex hasil dari budidaya sangat dipengaruhi oleh media hidupnya selama masa pemeliharaan. Menurut (Wenda, Pangkey, \& Mokolensang, 2018), bahwa kombinasi kotoran babi, kotoran ayam, kotoran sapi, dan lumpur halus yang ditambahkan dengan EM4 sebagai substrat budidaya cacing Tubifex terbukti menghasilkan pertambahan berat cacing Tubifex pada hari ke-28. Pemberian kombinasi limbah peternakan dan lumpur halus yang ditambahkan dengan EM4 sebagai pengkayaan pada media substrat cacing Tubifex diharapkan dapat menjadi solusi dalam meningkatkan ketersediaan cacing sutera, disertai dengan peningkatan biomassa cacing yang cukup besar dan juga peningkatan kandungan nutrisinya.

Berdasarkan hasil survei di lapangan, adanya keluhan dari masyarakat mengenai biaya produksi yang tinggi terutama pada kebutuhan pakan ikan budidaya, masyarakat 
belum memiliki kemampuan untuk membuat pakan sendiri karena keterbatasan pengetahuan, keterbatasan modal juga menjadi faktor yang tidak bisa dipungkiri. Pembuatan pakan buatan sendiri membutuhkan alat-alat tertentu dan beberapa bahan baku lainnya yang membutuhkan modal besar. Hal ini berdampak pada hasil produksi yang terbatas padahal permintaan ikan air tawar di wilayah ini cukup tinggi. Berdasarkan kondisi tersebut, maka perlu dilakukan kegiatan pengabdian kepada masyarakat di Desa Lubuk Saban berupa pelatihan membudidayakan pakan alami. Pakan alami yang akan dibudidayakan adalah cacing Tubifex sp. dengan memanfaatkan limbah sayuran dan peternakan sebagai media kulturnya. Harapan kami dengan pelatihan ini masyarakat dapat terbantu dalam membuka peluang usaha yang baru, menyediakan pakan alami, menekan biaya produksi, dan meningkatkan perekonomian masyarakat.

Dari analisis situasi dan permasalah mitra di atas, maka kami tim pengabdi memberikan beberapa solusi dan target luaran sebagai berikut :

1) Memberikan pelatihan budidaya pakan alami (Tubifex sp). Dari solusi ini diharapkan dapat :

a. Meningkatkan pengetahuan masyarakat tentang Tubifex sp.

b. Meningkatkan pengetahuan masyarakat tentang budidaya Tubifex sp.

c. Memunculkan minat masyarakat untuk membudiyakan Tubifex sp.

2) Memberikan analisis ekonomi peluang usaha Tubifex sp. Dari solusi ini diharapkan dapat:

a. Meningkatkan pengetahuan masyarakat tentang analisis ekonomi usaha budidaya Tubifex sp.

b. Memantapkan minat masyarakat untuk mulai membuka usaha budidaya Tubifex sp.

3) Memberikan pelatihan dan praktek budidaya Tubifex sp. Dari solusi ini diharapkan dapat :

a. Meningkatkan pengetahuan dan keterampilan masyarakat tentang prosedur budidaya Tubifex sp.

b. Pemanfaatan limbah sayuran diharapkan dapat menjadi solusi dari penumpukan sampah dan limbah peternakan.

\section{METODE}

Kegiatan pengabdian ini dilakukan di Desa Lubuk Saban Kecamatan Pantai Cermin Serdang Bedagai pada tanggal 19 Agustus 2019. Kegiatan dilakukan selama 3 jam dan dihadiri oleh para pelaku usaha budidaya ikan air tawar dan masyarakat non pelaku usaha budidaya. Mitra yang hadir berjumlah 20 orang di tunjuk langsung oleh kepala desa untuk mewakili setiap kelompok pembudidaya yang ada di Desa Lubuk Saban. Diharapkan dari 20 orang utusan kelompok ini dapat meneruskan informasi yang mereka dapatkan dari tim pengabdi untuk diterapkan pada kelompoknya masingmasing.

Metode atau pendekatan yang dilakukan tim pengabdi dalam kegiatan ini adalah berupa pengedukasian dan pelatihan langsung budidaya cacing Tubifex dengan susunan kegiatan adalah pemaparan materi pengabdian, diskusi interaktif berupa tanya 
jawab dan praktek langsung bagaimana cara persiapan dan budidaya cacing Tubifex dengan media limbah sayuran dan peternakan. Pemaparan materi dalam susunan kegiatan ini dibuat berdasarkan pertimbangan keterbatasan pengetahuan mitra tentang karakteristik dan budidaya cacing Tubifex tetapi berkeinginan kuat untuk mempelajari secara lebih rinci tentang ilmu dasar dari budidaya ini.

Kegiatan pengabdian ini dibagi atas 3 pemateri dengan masing-masing pemateri memberikan materi pengedukasian yang berkaitan dengan budidaya cacing Tubifex dan analisa ekonominya. Pemateri pertama memberikan materi mengenai karakteristik dan morfologi dari cacing Tubifex, pemateri kedua mengenai analisa ekonomi dari usaha budidaya cacing Tubifex, dan pemateri ketiga memberikan edukasi metode dan teknik dari budidaya cacing Tubifex. Setelah pemaparan materi, tim pengabdi melakukan diskusi berupa tanya jawab secara interaktif dan pembagian angket atau kuisioner sebagai timbal balik dan evaluasi bagi tim pengabdi.

\section{HASIL DAN PEMBAHASAN}

Kegiatan pengabdian kepada masyarakat di Desa Lubuk Saban ini dilakukan dengan menggunakan pendekatan edukatif yang berarti bahwa setiap kegiatan Pengabdian pada Masyarakat mengandung unsur-unsur pendidikan yang bertujuan untuk mengembangkan potensi masyarakat agar berdaya (mandiri) dalam menghadapi perubahan-perubahan dan mendinamisasi-kan masyarakat menuju kemajuan yang dicita-citakan (Asmuni, 2016).

Kegiatan pengabdian ini dilakukan dalam beberapa tahap yaitu tahap perencanaan/persiapan dan tahap edukasi dan pelatihan teknik budidaya cacing Tubifex sebagai salah satu peluang ekonomi bagi masyarakat Desa Lubuk Saban Kecamatan Pantai Cermin Kabupaten Serdang Bedagai disertai arti penting wirausaha bagi peserta pelatihan. Langkah awal yang dilakukan adalah persiapan kegiatan pengabdian meliputi observasi lokasi, kondisi dan temuan secara riil di lapangan dan mendiskusikan strategi, koordinasi dan pengurusan izin pelaksanaan kegiatan pengabdian serta menyepakati tanggal pelaksanaan di desa tersebut dengan perangkat desa.

Hasil survey menunjukkan bahwa permasalahan yang dihadapi oleh masyarakat pembudidaya ikan air tawar Desa Lubuk Saban antara lain 1) tingginya biaya pakan ikan budidaya sehingga berdampak terhadap menurunnya hasil produksi, padahal permintaan ikan air tawar di wilayah ini cukup tinggi; 2) keterbatasan pengetahuan dalam pembuatan pakan sendiri; dan 3) kurangnya modal para pembudidaya untuk melakukan usaha budidaya tersebut serta pembuatan pakan buatan sendiri membutuhkan alat-alat tertentu dan beberapa bahan baku lainnya yang membutuhkan modal besar. Berdasarkan tiga kendala tersebut, maka alternatif solusi yang dapat dilakukan adalah memberikan edukasi dan pelatihan membudidayakan pakan alami. Pakan alami yang akan dibudidayakan adalah Tubifex sp. dengan memanfaatkan limbah peternakan sebagai media kulturnya. Tahapan selanjutnya adalah tim pengabdi melakukan studi pustaka tentang teknik budidaya cacing Tubifex, melakukan persiapan alat dan bahan yang berhubungan dengan budidaya cacing Tubifex, menentukan waktu pelaksanaan dan susunan kegiatan pengabdian bersama-sama tim pelaksana, dan 
menentukan atau mempersiapakan materi yang akan disampaikan dalam kegiatan pelatihan budidaya cacing Tubifex nantinya.

Langkah kedua setelah tahap persiapan selesai, tim pengabdi melaksanakan sosialisasi dan pelatihan terkait budidaya cacing Tubifex di Desa Lubuk Saban. Pelatihan ini dilakukan dengan metode ceramah, diskusi, dan praktik langsung serta diakhir pelatihan dilakukan evaluasi kepada peserta pengabdian dengan memberikan angket/kuesioner berkaitan dengan seluruh kegiatan pengabdian. Penyuluhan tentang budidaya cacing Tubifex di laksanakan di Balai Desa Lubuk Saban dalam rangka merealisasikan pelaksanaan program pengabdian kepada masyarakat. Mitra yang digandeng dalam kegiatan pengabdian berjumlah 21 orang dibagi dalam 2 kelompok besar yang masing-masing kelompok terdiri dari 11 orang anggota. Pembagian kelompok dibuat dengan tujuan ketika sesi praktek, para peserta dapat lebih fokus menyerap materi dan teknik-teknik dalam melakukan usaha budidaya cacing Tubifex ini.

Mitra yang bekerja sama merupakan masyarakat yang menggeluti usaha budidaya ikan air tawar sehingga dalam pelaksanaan kegiatan penyuluhan tim pengabdi berupaya melakukan diskusi dengan masyarakat terhadap permasalahan yang dihadapi dan pemberian solusi atas masalah yang ditemukan oleh mitra. Hal yang didiskusikan dalam kegiatan tersebut adalah manfaat penggunaan pakan alami sebagai pengganti atau pendamping pakan buatan, sehingga selain kaya akan kandungan gizi juga dapat mengurangi biaya produksi dari kebutuhan pakan. Selain itu diskusi tentang struktur tubuh cacing Tubifex, siklus hidup dan cara reproduksi dari cacing ini juga menjadi topik yang menarik bagi pembudidaya, karena hal ini merupakan hal yang baru bagi peserta penyuluhan. Manfaat didapat, peserta dapat membedakan antara cacing tanah dengan cacing Tubifex sehingga jika suatu saat ingin mengambil cacing Tubifex dari alam untuk dibudidayakan sudah dapat membedakan antara kedua cacing tersebut. Dengan mengetahui siklus dan cara hidup cacing Tubifex, para peserta dapat menentukan kapan waktu memulai dan kapan waktu panen dilaksanakan.

Selanjutnya, tim pengabdi memberikan analisa ekonomi dari usaha budidaya cacing Tubifex ini. Berapa biaya-biaya yang harus dikeluarkan peserta jika melakukan usaha budidaya ini, biaya-biaya yang menjadi investasi dan keuntungan yang didapat mitra pengabdian jika melakukan usaha budidaya cacing Tubifex. Materi terakhir dari kegiatan penyuluhan ini adalah penyampaian materi teknik dan metoda dalam budidaya cacing Tubifex, persiapan alat dan bahan, membuat campuran media, meletakkan bibit cacing Tubifex ke media. Tahapan ini dilakukan langsung oleh mitra pengabdian dengan antusias. Target dari pelatihan ini adalah mitra pengabdian mampu membudidayakan Cacing Tubifex baik secara teori maupun praktik. Selain pelatihan, dukungan peralatan juga diberikan oleh tim pengabdi berupa bantuan alat berupa nampan besar, EM4, bibit cacing Tubifex, terpal, slang air, baskom, ember dan peralatan pendukung lainnya. Peralatan ini dapat digunakan secara berkelompok dan umum sesuai dengan peraturan dari kelompok mitra pengabdian. Kegiatan penyuluhan ditampilkan dalam Gambar 1. 


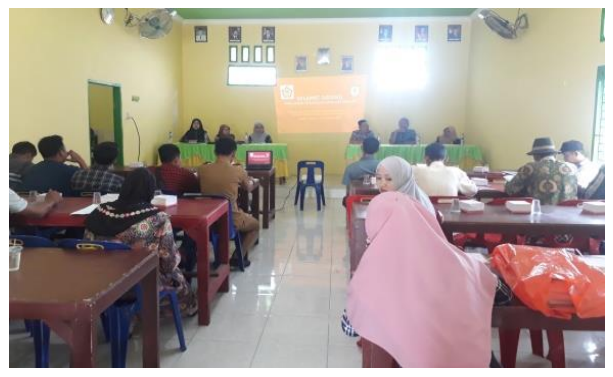

(1)

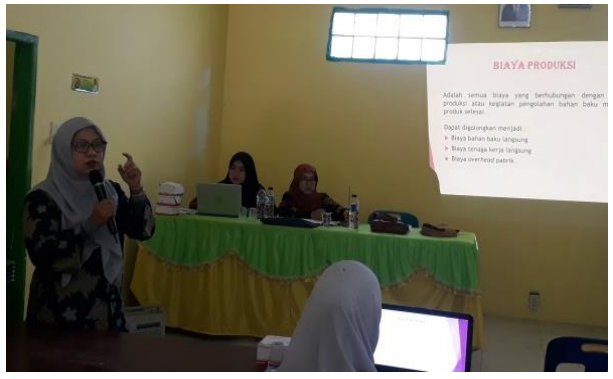

(3)

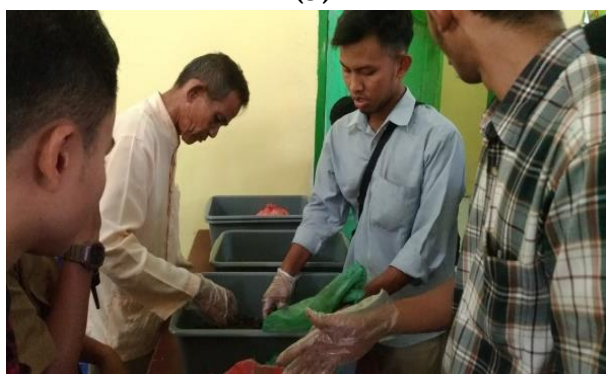

(5)

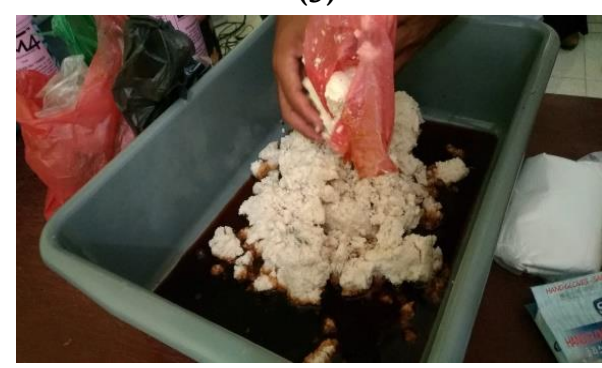

(7)

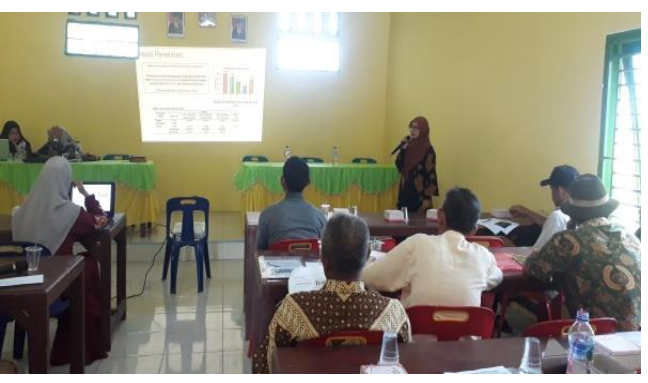

(2)

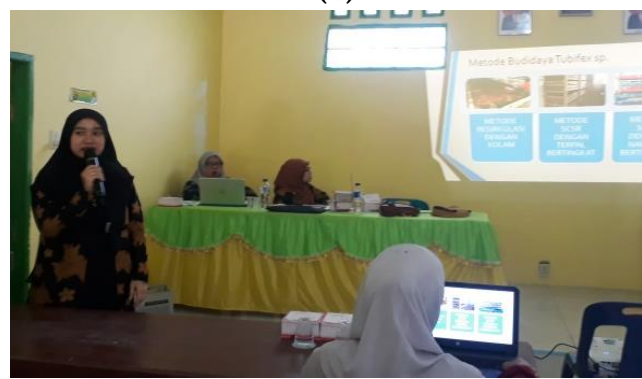

(4)

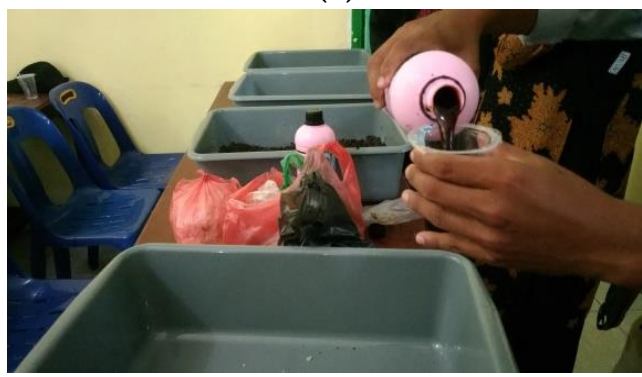

(6)

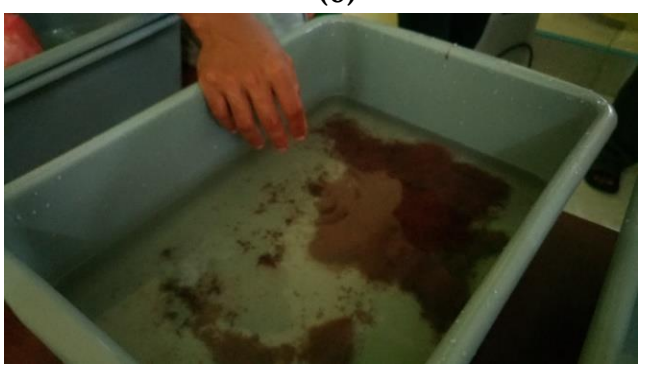

(8)

1). Kegiatan Penyuluhan Budidaya Cacing Tubifex; 2). Tim Pengabdi memberikan materi pertama yaitu "Mengenal Cacing Tubifex"; 3). Tim Pengabdi memberikan materi kedua yaitu "Analisa Ekonomi Budidaya Cacing Tubifex"; 4). Tim Pengabdi memberikan materi ketiga yaitu "Metode Budidaya Cacing Tubifex"; 5). Peserta melakukan praktek cara mempersiapkan media cacing tubifex; 6). Tahapan Selanjutnya memberikan Larutan EM4 pada media cacing tubifex; 7). Selanjutnya memberikan Limbah peternakan dan sayuran pada media sebagai pakan cacing tubifex; 8). Tahap terakhir adalah memasukkan cacing tubifex kedalam nampan yang telah berisi media

\section{Gambar 1. Kegiatan penyuluhan di Desa Lubuk Saban}


Sebagai umpan balik dan mengukur tingkat keberhasilan Program Pengabdian kepada Masyarakat (PKM) ini maka tim pengabdi memberikan angket kepada mitra pengabdian dengan beberapa pertanyaan dan evaluasi terhadap keseluruhan proses. Hasil evaluasi menunjukkan bahwa kegiatan ini memenuhi kriteria keberhasilan yang telah ditetapkan. Hal ini dapat dilihat dari kriteria keberhasilan, yaitu:

1) $90 \%$ tingkat wawasan, pengetahuan dan pemahaman tentang usaha budidaya cacing tubifex dapat diserap (dikuasai) oleh mitra masyarakat. Ini dapat dilihat dari respon, minat, kepuasan dan diskusi interaktif antara masyarakat mitra dengan tim pengabdi selama kegiatan Pengabdian berlangsung sangat baik.

2) Setelah penyuluhan, tim pengabdi mendemontrasikan teknik meramu media dan pakan dalam nampan sebagai tempat hidup cacing tubifex. Selanjutnya peserta diberi kesempatan untuk mempraktekan sendiri tentang teknik meramu media dan pakan dalam nampan sebagai tempat hidup cacing tubifex. Berdasarkan pengamatan terhadap kemampuan dan ketrampilan mitra dalam menerapkan teknik meramu media dan pakan dalam nampan terlihat sekitar $90 \%$ dari seluruh mitra pengabdian mampu melakukan pembuatan media untuk tumbuh kembang cacing tubifex.

Target luaran hasil pengabdian kepada masyarakat di Desa Lubuk Saban telah memenuhi kriteria keberhasilan yang telah ditetapkan sebelumnya. Hal ini dikarenakan hubungan atau keterkaitan antara materi dengan praktek dan kebutuhan dapat diserap dengan baik oleh masyarakat mitra. Waktu yang dipergunakan dalam pemberian materi dan teknik penyajian dari tim pengabdi dinilai sangat baik oleh masyarakat mitra.

\section{SIMPULAN}

Setelah melakukan kegiatan pengabdian edukasi usaha budidaya cacing Tubifex sebagai pakan alami bagi kelompok pembudidaya ikan di Desa Lubuk Saban, maka dapat disimpulkan bahwa seluruh kegiatan Pengabdian Kepada Masyarakat dapat dilaksanakan dan terealisasi sesuai dengan perencanaan. Indikator capaian yang ditetapkan telah berhasil dicapai diantaranya adalah: Hasil evaluasi tingkat pemahaman penguasaan materi pengabdian diperoleh bahwa 90\% masyarakat mitra pengabdian menguasai dan memahami tentang: siklus hidup cacing Tubifex, analisa ekonomi dari usaha budidaya cacing Tubifex dan metode budidaya cacing Tubifex yang efisien dan efektif. Transfer pengetahuan dan teknologi dapat diterima dan dipraktekkan oleh masyarakat mitra terutama kelompok pembudidaya ikan tawar

Saran yang dapat kami usulkan adalah keberlanjutan kegiatan pengabdian masyarakat mengenai cara budidaya cacing Tubifex dengan melakukan pendampingan, monitoring dan evaluasi dari kegiatan tersebut sehingga diharapkan komitmen masyarakat mitra akan terus tumbuh dalam mengembangkan budidaya cacing Tubifex sebagai upaya keberlanjutan program. 


\section{Ucapan Terimakasih}

Terimakasih diucapkan kepada Lembaga Pengabdian kepada Masyarakat Universitas Dharmawangsa yang telah membiayai kegiatan ini melalui Skim Pengabdian Masyarakat Hibah Internal Periode III Universitas Dharmawangsa Tahun 2019.

\section{REFERENSI}

Asmuni. (2016). Hakikat Pengabdian pada masyarakat dan arah kebijakan kuliah kerja nyata di STKIP PGRI Jombang. Jombang: STKIP PGRI Jombang. https://doi.org/10.13140/RG.2.2.29394.56008

Bintaryanto, B. W., \& Taufikurohmah, T. (2013). Pemanfaatan campuran limbah padat (Sludge) pabrik kertas dan kompos sebagai media budidaya cacing sutra (Tubifex .Sp). UNESA Journal of Chemistry, 2(1), 1-7.

Setyaningrum, N., Sugiharto., \& Sukmaningrum, S. (2016). Budidaya cacing rambut (Tubifex Sp) dengan fermentasi limbah organik sebagai pakan alami ikan gurami. In Pengembangan Sumber Daya Perdesaan dan Kearifan Lokal Berkelanjutan VI (Vol. 8, pp. 1-7). Purwokerto: Lembaga Penelitian dan Pengabdian Kepada Masyarakat Universitas Jenderal Soedirman.

Suharyadi. (2012). Studi Penumbuhan dan Produksi cacing Sutra (Tubifex sp ) dengan Pupuk yang berbeda dalam sistem resirkulasi. Jakarta: Universitas Terbuka. Retrieved from http://repository.ut.ac.id/445/

Wenda, D., Pangkey, H., \& Mokolensang, J. F. F. (2018). Pemanfaatan kotoran ternak dengan dosis yang berbeda terhadap pertumbuhan dan biomassa cacing sutra (Tubifex sp.). E-Journal BUDIDAYA PERAIRAN, 6(2), 25-31. https://doi.org/10.35800/bdp.6.2.2018.20496

\section{Copyright and License}

This is an open access article distributed under the terms of the Creative Commons Attribution 4.0 International License, which permits unrestricted use, distribution, and reproduction in any medium, provided the original work is properly cited. (C) 2020 Emmy Syafitri, Dwi Tika Afriani, Mekar Meilisa Amalia. 